\title{
The Cultivation of Some Rumen Oligotrich Protozoa
}

\author{
By R. T. J. CLARKE* \\ Massey University College of Manawatu, \\ Palmerston North, New Zealand
}

(Received 7 May 1963)

\begin{abstract}
SUMMARY
The rumen oligotrich protozoa, Eremoplastron bovis (Dogiel, 1927), E. brevispinum (Kofoid \& MacLennan, 1932), Entodinium longinucleatum (Dogiel, 1925), E. ovinum (Dogiel, 1927), Eudiplodinium maggii (Fiorentini, 1889) and various Epidinium species have been cultured in mixed culture for over 7 months. The medium consisted of rice starch, dried grass and casein in a mineral salt solution + rumen liquor. No antibiotics were used. Preliminary studies showed that sodium sulphide causes inhibition of protozoal metabolism in concentrations greater than $0.01 \%$. Pure cultures of Epidinium ecaudatum (Fiorentini, 1889) and Eremoplastron bovis have been established. In addition, a clone of $E$. bovis was maintained for 5 months. A method for growing quantities of protozoa for biochemical studies is described.
\end{abstract}

\section{INTRODUCTION}

The holotrich protozoa of the rumen still defy all attempts at culture, but some success has been obtained with the oligotrichs. The first advance was made by Hungate (1942, 1943), who maintained some oligotrich species for over a year. Coleman (1960) cultured oligotrichs, principally Entodinium caudatum, for over 18 months, and Gutierrez \& Davis (1962) maintained Epidinium ecaudatum for 6 months. Kandatsu \& Takahashi (1956) reported the culture of species of Entodinium for 30 days, with some division, but rumen ciliates maintained for this period cannot be considered to constitute a culture since Coleman (1960) demonstrated that some dietary treatments may result in gradual loss of the protozoa for periods of up to nearly 50 days.

Investigations into the biochemistry of rumen protozoa have been hampered by the lack of pure cultures, and most studies have been made on washed suspensions prepared from rumen contents. Studies have been confined to those ciliates which, through some dietary or environmental factor, have been present in large numbers in a particular animal. As a result of this limitation, the biochemistry of many rumen ciliates has yet to be investigated. Metabolic studies with washed suspensions of protozoa, and with protozoa from bacteria-containing cultures, have required the use of antibiotics to suppress bacterial activity (Abou Akkada \& Howard, 1960). Antibiotics have, in general, also been used to inhibit bacteria in protozoal cultures and Coleman (1960) attributed part of his success in cultivating entodinia to the presence of chloramphenicol in the medium. Attempts (Coleman, 1962) to prepare axenic cultures were unsuccessful. However, since the development by

* Present address : Plant Chemistry Division, Department of Scientific and Industrial Research. Palmerston North, New Zealand. 
Bailey \& Howard (1962) of a specific method for disrupting protozoa, without disruption of associated bacteria, bacteria-free ciliate preparations are no longer necessary for enzyme studies, although they are still required for manometric investigations. To make preparations of single species of rumen oligotrichs available for biochemical studies, oligotrich cultures have been established in this laboratory. This paper describes the successful cultivation of a range of rumen oligotrichs, and the establishment of a clone of one species. An apparatus suitable for preparing large numbers of cells for biochemical studies is also described.

\section{METHODS}

Mineral salt solution. The mineral salt solution contained (g./l.): $\mathrm{K}_{2} \mathrm{HPO}_{4}, 0 \cdot \mathbf{5}$; $\mathrm{KH}_{2} \mathrm{PO}_{4}, 1 \cdot 0 ; \mathrm{NaCl}, 3 \cdot 0 ; \mathrm{MgSO}_{4} \cdot 7 \mathrm{H}_{2} \mathrm{O}, 0 \cdot 1 ; \mathrm{CaCl}_{2}, 0 \cdot 008$; sodium acetate $3 \mathrm{H}_{2} \mathrm{O}, 1 \cdot 8$. Freeze-dried, clarified rumen liquor, 1.4 g., or fresh, clarified rumen liquor, $100 \mathrm{ml}$., was added and the solution was autoclaved in 1 l. screw-capped bottles. $\mathrm{NaHCO}_{3}$, 1.0 g., and $\mathrm{Na}_{2} \mathrm{~S} .9 \mathrm{H}_{2} \mathrm{O}, 0.1 \mathrm{~g}$., or cysteine $\mathrm{HCl}, 1.0 \mathrm{~g}$., were added just before use.

Dried grass. Perennial ryegrass (Lolium perenne, L.) was dried at $55^{\circ}$ for 2 days. After grinding in a ball mill for $6 \mathrm{hr}$. the finely divided grass was passed through a 100 mesh (aperture $152 \mu$ ) sieve.

Rice starch. Starch was prepared from rice by the method of Whelan (1955).

Casein. Casein (B.D.H.) was dissolved in $\mathrm{N}-\mathrm{NaOH}$. After adjusting to $\mathrm{pH} \mathbf{7 \cdot 4}$ and filtering through glass wool, the solution was freeze-dried.

Cellulose. Finely divided cellulose was prepared from absorbent cottonwool. The cotton was digested with $10 \mathrm{~N}-\mathrm{HCl}$ for $24 \mathrm{hr}$., washed, and ground in a ball mill for $96 \mathrm{hr}$. The suspension of cellulose particles was freeze-dried.

Rumen liquor. Clarified rumen liquor from a cow on a diet of red clover (Trifolium pratense, L.) or clover hay was obtained by centrifuging fresh rumen liquor at $10,000 \mathrm{~g}$ for $30 \mathrm{~min}$. The clear solution was either freeze-dried or added to the mineral salt solution and autoclaved.

Volatile acids. Total volatile acids were determined by steam-distillation, followed by titration with $\mathrm{NaOH}$ in a $\mathrm{CO}_{2}$-free atmosphere.

Lactic acid. Lactic acid was determined by the method of Barker \& Summerson (1941).

\section{Cultures}

Inoculum. Protozoa were prepared by the method of Oxford (1958) from the rumen liquor of a cow feeding on fresh red clover. The suspension contained holotrichs and species of the following oligotrich genera (see Kofoid \& MacLennan, 1930, 1932, 1933): Entodinium, Eodinium, Eremoplastron, Epidinium, Eudiplodinium, Metadinium, Ostracodinium, Diplodinium. The bulk of the oligotrichs consisted of Entodinium (20\%), Eremoplastron (30\%), Epidinium (35\%), and Eudiplodinium $(\mathbf{1 0} \%)$. The other oligotrichs were present in low numbers.

Cultures. The protozoa were grown in $100 \mathrm{ml}$. glass-stoppered conical flasks. Rice starch, $10 \mathrm{mg}$., casein, $4 \mathrm{mg}$., and dried grass, $10 \mathrm{mg}$., were added to the basal medium. No antibiotics were added. The flasks were thoroughly gassed with $\mathrm{CO}_{2}$ before addition of the inoculum, and when any addition or transfer was made. Additions of substrate were made every $24 \mathrm{hr}$. Every $48 \mathrm{hr}$. the protozoa were transferred by carefully decanting the bulk of the supernatant fluid and pouring 
the residue into a new flask containing fresh medium and substrate. Unless care was taken in the initial and final decantations, a considerable number of protozoa were lost. During routine culture the loss of these protozoa tended to keep the numbers constant in spite of the continued division of the organisms.

Large-scale culture. Protozoa for metabolic studies and enzyme experiments have been grown in the following apparatus. A 5 l. carboy with a flat bottom, and fitted with a siphon overflow adjusted to maintain a liquid volume of 21 ., was used as the growth vessel. Constant temperature was maintained by immersing the growth vessel in a thermostatically controlled water-bath. Fresh basal medium at room temperature was continuously added (900 ml./hr.) with a peristaltic pump (Sigmamotor Inc., Middleport, N.Y., U.S.A.) governed with a Revco 'Zeromax' speedchanger (Zeromax Co., Minnesota, U.S.A.). The system was flushed with $\mathrm{CO}_{2}$ before inoculation, and after each addition of substrate, which was made manually every $\mathbf{2 4} \mathrm{hr}$. The amounts of substrate added were increased as protozoal numbers increased. At the beginning of the experiment $10 \mathrm{mg}$. dried grass and $10 \mathrm{mg}$. rice starch were added every $24 \mathrm{hr}$. These amounts were increased daily until, after 9-12 days, $500 \mathrm{mg}$. dried grass and $1 \mathrm{~g}$. rice starch were added. At the end of the growth period the protozoa were recovered by low-speed centrifugation.

Single-organism cultures. Single-organism cultures were initiated with single organisms isolated by using a microscope and micro-pipette. To facilitate their isolation, the protozoa were immobilized with $0 \cdot 1 \%$ sodium barbitone. Provided that the protozoa were not exposed to barbitone for more than $4 \mathrm{~min}$. they revived satisfactorily when placed in fresh medium. The cultures were started in $5 \mathrm{ml}$. conical flasks, and were transferred to larger flasks as the ciliates multiplied.

\section{Manometric studies}

Manometric studies on the effect of sodium sulphide on suspensions of protozoa were carried out in $150 \mathrm{ml}$. Warburg-type flasks at $39^{\circ}$.

Each flask contained $40 \mathrm{ml}$. of a heavy suspension of protozoa and $10 \mathrm{ml}$. of juice expressed from macerated red clover. The flasks were gassed with $95 \% \mathrm{~N}_{2}+5 \% \mathrm{CO}_{2}$ and were gently shaken during the experiment. Gas evolution was measured in $200 \mathrm{ml}$. constant pressure manometers attached to the flasks with butyl rubber tubing. The protozoa were prepared from rumen liquor by low-speed centrifugation. Each batch was washed free of extraneous bacteria, divided into equal parts and suspended in either the buffer of Coleman (1958), with either sodium sulphide or cysteine- $\mathrm{HCl}$ as reducing agent, or in clarified rumen liquor.

\section{Microscope technique}

Counts. The protozoa were counted in a cell constructed from microscope slides as described by Boyne, Eadie \& Raitt (1957). Before counting, the protozoa were fixed in $10 \%(\mathrm{v} / \mathrm{v})$ formalin and stained with $0.01 \%$ aqueous methyl green.

Identification. The ciliates were identified after staining with methyl green, iodine, or chlor-zinc-iodide, and mounting in water or $50 \%(\mathrm{v} / \mathrm{v})$ aqueous glycerol. The identification was based on the classification of Kofoid \& MacLennan (1930, 1932, 1933). 


\section{RESULTS}

\section{Preliminary investigations}

Following an observation that sodium sulphide sometimes inhibited the metabolism of rumen ciliates, an investigation of this effect was carried out. Manometric experiments with washed protozoa suspended in clarified rumen liquor, cysteine HCl buffer and sodium sulphide buffer demonstrated a 31-39\% decrease in gas production and a $\mathbf{2 3 - 3 7 \%}$ decrease in volatile acid production in the presence of $0.02 \%$ sodium sulphide. There was also a slight and variable decrease in the amount of lactic acid produced. The results of three experiments are shown in Table 1. With $\mathbf{0 . 0 1} \%$ sodium sulphide, end-products were decreased by $4-8 \%$. Below this concentration, the reducing effect of the added sulphide was not sufficient for continued protozoal activity.

Table 1. Effect of reducing agents on protozoal metabolism

\begin{tabular}{|c|c|c|c|c|c|}
\hline & & Protoz & $\begin{array}{l}\text { pended } \\
\text { ) buffer }\end{array}$ & $\begin{array}{l}\text { Coleman's } \\
\text { th }\end{array}$ & \\
\hline End-products & & Sodiv & phide & & Protozoa suspended \\
\hline $60 \mathrm{~min}$. & & $0.01 \%$ & $0.02 \%$ & $0.01 \%$ & liquor \\
\hline Gas (ml.) & (1) & 30 & 22 & 32 & 30 \\
\hline & (2) & 31 & 20 & 33 & 32 \\
\hline & (3) & 24 & 17 & 26 & 26 \\
\hline Volatile acids & (1) & $\mathbf{2 \cdot 9}$ & $2 \cdot 3$ & $3 \cdot 0$ & $3 \cdot 0$ \\
\hline (m-mole) & (2) & $\mathbf{2 \cdot 9}$ & $2 \cdot 0$ & $3 \cdot 1$ & $3 \cdot 0$ \\
\hline & (3) & $1 \cdot 9$ & $1 \cdot 2$ & $1 \cdot 9$ & $1 \cdot 8$ \\
\hline Lactic acid & (1) & $0 \cdot 96$ & $0 \cdot 87$ & $1 \cdot 05$ & 0.98 \\
\hline (m-mole) & (2) & $0 \cdot 74$ & $0 \cdot 69$ & $0 \cdot 88$ & $0 \cdot 87$ \\
\hline & (3) & 0.51 & $0 \cdot 50$ & 0.54 & $0 \cdot 61$ \\
\hline
\end{tabular}

When the present cultures of the ciliates were initiated, cysteine $\mathrm{HCl}(0 \cdot 1 \%)$ and sodium sulphide $(0.01 \%)$ were used in parallel series as reducing agents in the medium. For the first 20-25 days, the medium with cysteine $\mathrm{HCl}$ supported the growth of more ciliates than the medium with sodium sulphide. After that period the difference diminished and the cultures have since been maintained using sodium sulphide $(0.01 \%)$ as reducing agent.

In early attempts at culture, the protozoa were incubated with antibiotics ( $\mathrm{K}$ benzylpenicillin $0.004 \%$, neomycin sulphate, $0.003 \%$ ), rumen liquor, rice starch and casein, and, for the first $24 \mathrm{hr}$., with mannose, $0.5 \%$, to kill the holotrichs (Sugden \& Oxford, 1952). The oligotrichs in these cultures did not survive more than 5 days. Omission of the mannose and the antibiotics extended the life of the cultures to 14-16 days. Cultures without mannose in the preliminary stages, and without antibiotics, grew readily when dried grass was added.

\section{Observations on cultures}

Dried grass. Established cultures from which grass was omitted died within 10 days. The grass could not be replaced by a freeze-dried aqueous extract of grass, although in the presence of this extract a few protozoa persisted for over 20 days. 
Rice starch and cellulose. Cultures without starch persisted indefinitely provided that grass or casein was present, but the ciliates were never numerous. The replacement of rice starch with cellulose resulted in cultures containing mainly Eudiplodinium maggii and species of Epidinium with a few Eremoplastron bovis. The other ciliates died within 10 days.

Casein. The omission of casein from the cultures made little obvious short-term difference, but, over a period of several weeks, cultures with casein produced more organisms than cultures without casein. This was a visual observation and no counts were made. Sodium caseinate, Difeo (Nutrose), $4 \mathrm{mg} . / 100 \mathrm{ml}$., caused death of the ciliates in 4 days.

Rumen liquor. Rumen liquor was essential for the survival and growth of the ciliates; cultures without it survived less than 10 days. Freshly prepared or freezedried rumen liquor were equally beneficial whether added directly to the autoclaved basal solution or autoclaved when mixed with the basal solution. Rumen liquor autoclaved undiluted caused death of the protozoa within $30 \mathrm{~min}$. Bacto Yeast Extract, $5 \mathrm{mg} . / 100 \mathrm{ml}$., added as a replacement for the rumen liquor, caused death of the ciliates within $2 \mathrm{hr}$.

Antibiotics. Terramycin, viomycin, $\mathrm{K}$ benzylpenicillin, penicillin G, neomycin sulphate, streptomycin sulphate and achromycin all killed the ciliates in 2-24 hr. when added to the cultures at a final concentration of $50 \mu \mathrm{g} . / \mathrm{ml}$. Achromycin, $5 \mu \mathrm{g} . / \mathrm{ml}$., controlled bacterial growth, but only for a few hours. At various lower concentrations the other antibiotics were not toxic, but they did not inhibit bacterial growth. Chloramphenicol, $50 \mu \mathrm{g} . / \mathrm{ml}$., had no obvious effect on the ciliates, but bacterial growth was not suppressed enough to warrant its use. Higher concentra tions were rapidly toxic.

All the cultures have been maintained without the benefit of antibiotics. Bacterial growth caused only a slight turbidity in the cultures unless the starch was above $0.25 \mathrm{mg} . / \mathrm{ml}$.

Oxidation-reduction potential. After gassing, but before inoculation, the redox potential of the culture fluid was approximately $-280 \mathrm{mV}$. The potential dropped to approximately $-410 \mathrm{mV}$. after $48 \mathrm{hr}$. incubation.

Rates of division. Division times were obtained by calculating the number of divisions occurring in a given period, from the number of ciliates produced. No growth curves were made for the cultures. One culture with casein, dried grass and rice starch (10 mg.) had a mean division time of approximately $21 \mathrm{hr}, 500,000$ protozoa being produced in 8 days from an inoculum of 1000 cells. On another occasion a similar culture had a mean division time of $15 \mathrm{hr}$. over a 9-day period.

\section{Cultures established}

The following oligotrichs have now been maintained, dividing, in mixed culture for over 6 months: Eremoplastron bovis (Dogiel, 1927), E. brevispinum (Kofoid \& MacLennan, 1932), Entodinium longinucleatum (Dogiel, 1925), E. ovinum (Dogiel, 1927), Eudiplodinium maggii (Fiorentini, 1889), and some species of Epidinium. In addition, pure cultures of an Epidinium species and of $E$. bovis have been established. A clone of $\boldsymbol{E}$. bovis was maintained for 5 months before it was accidentally contaminated with epidinia. The clone was grown from a single cell isolated after sodium barbitone treatment. 
Morphological variation. Considerable variation took place in the cultures over a period of several months. The mixed cultures originally contained 1-5 spined members of the 'caudatum' group of epidinia, but, after 7 months, none of the epidinia exhibit caudal spination. The pure culture of an Epidinium species which has been established does not exhibit caudal spination although all of the epidinia in the original inoculum had spines. The culture is presumably now Epidinium ecaudatum (Fiorentini, 1889).

The clone of Eremoplastron bovis also changed in character. Originally started with a single organism measuring about $45 \times 80 \mu$, the clone developed forms measuring 30-50 $\times 55-90 \mu$, with varying types of caudal lobes. These new forms are similar to E. bovis, E. monolobum and E. brevispinum.

\section{DISCUSSION}

The conditions of culture described here differ in various aspects from those described by Hungate (1942, 1943), Coleman (1960) and Gutierrez \& Davis (1962). Thus Hungate and Gutierrez \& Davis did not find rumen liquor necessary for the growth of their ciliates, while Coleman found both rumen liquor and antibiotics essential. Antibiotics, rather than being essential, probably help to increase the total yield of ciliates. Thus Coleman (1960), using chloramphenicol, cultured entodinial populations of $30,000 / \mathrm{ml}$, whereas in the present work, without antibiotics, the ciliates reached only 2500/ml. and Gutierrez \& Davis (1962) and Hungate (1942) achieved populations of 1200/ml. Kandatsu \& Takahashi (1956), however, raised entodinial populations of $50,000 / \mathrm{ml}$. in the absence of antibiotics.

The size of the ciliates being cultured probably determines the final population density to some extent. It has been observed that there is a high mortality among ciliates in a thick layer on the bottom of a flask. Entodinia are, in general, smaller than the other oligotrichs and probably attain a higher density/unit area by virtue of their small size. This may be one reason why Coleman (1960) was able to culture 30,000 entodinia/ml. Some of the organisms cultured here, and those cultured by Gutierrez \& Davis (1962) are considerably larger than most entodinia.

Hungate $(1942,1943)$ did not use reducing agents in his culture medium and Gutierrez \& Davis (1962) apparently used cysteine HCl; Coleman (1960) used $0.01 \%$ sodium sulphide. In view of the inhibitory effect of the concentrations of sodium sulphide shown here, some of the unsuccessful attempts to culture rumen ciliates may have failed partly because of the toxic concentrations used. For example, Oxford (1958) used $0.08 \%$ sodium sulphide and the epidinia survived for only 8 days.

Many attempts were made to establish cultures from isolated single organisms following treatment of the protozoa with sodium barbitone, but only one culture was successful. The barbitone did not seem to have any adverse effect on the protozoa and recovery of the organisms was complete in all cases. The failure of most of the attempts was probably the result of the difficulties involved in handling the isolated organisms in subsequent manipulations. It is difficult to transfer a few ciliates into fresh medium because of the ease with which the organisms are lost in the grass debris.

Morphological variation in cultures of rumen ciliates has long been established. 
Poljansky \& Strelkow (1934) showed that clones of Eremoplastron bilobum developed forms similar to $E$. bovis and E. monolobum, and Hungate (1942) noticed similar variation in his cultures of Eudiplodinium neglectum (Dogiel, 1927; Eremoplastron species, Kofoid \& MacLennan, 1932). The clonal variation of $E$. bovis found here was similar. The loss or change of caudal spination in Epidinium was also noticed by Gutierrez \& Davis (1962). Although this variability has only been demonstrated in vitro, it is a useful argument against the division of composite groups of protozoa into species, as carried out by Kofoid \& MacLennan (1932). Further work on the establishment of clones of rumen ciliates is warranted, as their study will undoubtedly clarify the classification of this group.

The large-scale apparatus is useful for the preparation of protozoa for biochemical studies. With a minimum of effort it is not difficult to produce several g. wet wt. organisms, a lengthy and time-consuming task when using $100 \mathrm{ml}$. flasks as culture vessels.

I wish to thank my two supervisors, Dr J. C. Hawke and Dr A. T. Johns, for their encouragement and helpful advice. I am grateful to Dr B. H. Howard of the Rowett Research Institute, Aberdeen, for his assistance at the commencement of this work, while he was working in this laboratory.

\section{REFERENCES}

Abou Akkada, A. R. \& Howard, B. H. (1960). The biochemistry of rumen protozoa. 3. The carbohydrate metabolism of Entodinium. Biochem. J. 76, 445.

BaIley, R. W. \& Howard, B. H. (1962). Preparation of enzymes from rumen protozoa by indole disintegration. Arch. Biochem. Biophys. 99, 299.

Barker, S. B. \& Summerson, W. H. (1941). The colorimetric determination of lactic acid in biological material. J. biol. Chem. 138, 535.

Boyne, A. R., EADIE, J. M. \& RAITT, K. (1957). The development and testing of a method of counting rumen ciliate protozoa. J. gen. Microbiol. 17, 414.

Coleman, G. S. (1958). Maintenance of oligotrich protozoa from the sheep rumen in vitro. Nature, Lond. 182, 1104.

Coleman, G. S. (1960). The cultivation of sheep rumen oligotrich protozoa in vitro. J. gen. Microbiol. 22, 555.

Colsman, G. S. (1962). The preparation and survival of almost bacteria-free suspensions of Entodinium caudatum. J. gen. Microbiol. 28, 271.

Dogrel, V. A. (1925). Neue parasitische Infusorien aus dem Magen des Renntieres. (Rangifer tarandus). Arch. russes Protist. 4, 43.

Dogrel, V. A. (1927). Monographie der Familie Ophryoscolecidae. Arch. Protistenk. 59, 1. Fionentini, A. (1889). Intorno ai protisti dello stomaco dei bovini. Pavia: Frat. Fusi.

Gutierrez, J. \& Davis, R. E. (1962). Culture and metabolism of the rumen ciliate Epidinium ecaudatum Crawley. Appl. Microbiol. 10, 305.

Hungate, R. E. (1942). The culture of Eudiplodinium neglectum, with experiments on the digestion of cellulose. Biol. Bull., Woods Hole, 83, 303.

Hungate, R. E. (1943). Further experiments on cellulose digestion by the protozoa in the rumen of cattle. Biol. Bull., Woods Hole, 84, 157.

Kandatsu, M. \& Takahashi, N. (1956). Studies on reticulo-rumen digestion. Part 4. On the artificial culture of some entodinia. III. J. agric. chem. Soc. Japan, 30, 96.

Kofoid, C. A. \& Maclennan, R. F. (1930). Ciliates from Bos indicus Linn. I. The genus Entodinium Stein. Univ. Calif. Publ. Zool. 33, 471.

Kofoid, C. A. \& Maclennan, R. F. (1932). Ciliates from Bos indicus Linn. II. A revision of Diplodinium Schuberg. Univ. Calif. Publ. Zool. 37, 53. 
Kofoid, C. A. \& Maclennan, R. F. (1933). Ciliates from Bos indicus Linn. III. Epidinium Crawley, Epiplastron gen. nov., and Ophryoscolex Stein. Univ. Calif. Publ. Zool. 39, 1.

OxFord, A. E. (1958). Bloat in cattle. IX. Some observations on the culture of the cattle rumen ciliate Epidinium ecaudatum Crawley occurring in quantity in cows fed on red clover (Trifolium pratense L.). N.Z. J. agric. Res. 1, 809.

Poljansky, G. \& Strelkow, A. (1934). Beobachtungen über die Variabilität einiger Ophryoscolecidae (Infusoria Entodiniomorpha) in Klonen. Zool. Anz. 107, 215.

Sugden, B. \& OXford, A. E. (1952). Some cultural studies with holotrich ciliate protozoa of the sheep's rumen. J. gen. Microbiol. 7, 145.

Whelan, W. J. (1955). In Modern Methods of Plant Analysis, 2, p. 160. Ed. by K. Paech \& M. V. Tracey. Berlin: Springer. 